\title{
RESISTANCE TO THERAPY IN MATURE PALMERSTON NORTH MICE TREATED WITH CYCLOPHOSPHAMIDE OR HYDROCORTISONE SODIUM SUCCINATE
}

\author{
SARA ELLEN WALKER and BERTRAM SCHNITZER
}

Inbred Palmerston North (PN) mice are a newly recognized model of systemic lupus erythematosus. In this study PN mice with established autoimmune disease were treated until death with cyclophosphamide $(8$ $\mathrm{mg} / \mathrm{kg} / \mathrm{day})$ or hydrocortisone $(10 \mathrm{mg} / \mathrm{kg} / \mathrm{day})$. These doses had previously been found to prevent or suppress disease in another lupus model, the NZB/NZW mouse. In the PN strain, autoantibodies, severity of glomerulonephritis, and longevity were not influenced by treatment. Furthermore, the incidence of neoplasms was not increased in PN mice receiving prolonged therapy with immunosuppressive drugs. Unlike NZB/NZW mice, PN mice were resistant to the effects of cyclophosphamide and hydrocortisone.

Inbred mice of the Palmerston North (PN) strain spontaneously develop a disease similar to systemic lupus erythematosus (SLE) in humans. These animals have positive indirect immunofluorescent tests for antinuclear antibodies (ANA), antibodies to DNA (antiDNA), LE cells, glomerulonephritis, and arteritis (1). The availability of this newly recognized strain of au-

From the University of Michigan Medical School, Ann Arbor, Michigan

Supported by Grants 5 R01 CA13297 from the National Cancer Institute and I R01 AM25543 from the National Institutes of Health, US Public Health Service and Research Grants from the Michigan Chapter of the Arthritis Foundation and the Michigan Lupus Foundation.

Sara Ellen Walker, MD: Associate Professor of Medicine, Rackham Arthritis Research Unit, Department of Internal Medicine; Bertram Schnitzer, MD: Professor of Pathology, Department of Pathology.

Address reprint requests to Sara Ellen Walker, MD, R4633 Kresge I Research Building, 1405 East Ann Street, Ann Arbor MI 48109 .

Submitted for publication November 29, 1979; accepted in revised form January 15, 1980. toimmune mice provided an opportunity to treat their lupus-like disease with immunosuppressive drugs.

Earlier studies showed that alkylating agents and corticosteroids were effective in treating autoimmune disease in another animal model of SLE, the hybrid New Zealand Black/New Zealand White (NZB/NZW) mouse. When mature NZB/NZW mice with active disease received cyclophosphamide or betamethasone, autoantibody production and glomerulonephritis were suppressed $(2,3)$. Furthermore, an increased incidence of neoplasms was observed in NZB/NZW mice with established disease, which had received prolonged treatment with cyclophosphamide $(4,5)$.

In the current study the immunosuppressive effects and oncogenic properties of cyclophosphamide and hydrocortisone were investigated in a mouse strain that was genetically different from New Zealand mice. PN mice with established autoimmune disease received lifelong therapy with immunosuppressive doses of cyclophosphamide or hydrocortisone. Glomerulonephritis was suppressed in cyclophosphamide-treated PN females, but therapy did not control autoantibody production or increase longevity in mice of either sex. Occurrence of neoplasms did not increase in treated mice. It was concluded that two drugs which suppressed established autoimmune disease in New Zealand mice were not effective in treating the lupus-like disease of mature PN mice.

\section{MATERIALS AND METHODS}

Animals. Mice used in this study were inbred descendents of PN mice in F27-F30 generations obtained from Dr. Richard D. Wigley in Palmerston North, New Zealand, in March 1974 (1). Two groups of mice were treated: Group Isixty-two PN mice (32 females and 30 males) in generations 
F28-F31 were entered in the study in November 1974. These mice, descended from stock that carried chronic respiratory disease (6), were kept in conventional animal quarters. Group II--fifty-seven mice ( 27 females and 30 males) in F35-F37 generations were born and housed in a laminar flow hood. Group II mice were the offspring of F34 PN mice which had been delivered by cesarean section and raised on pathogenfree CD-1 mothers (Charles River Laboratories, Portage Michigan) in a laminar flow hood. Group II mice entered the study in February 1977.

Animals used in these experiments were maintained in facilities fully accredited by the American Association for Accreditation of Laboratory Animal Care. Experiments were conducted according to the Guide for the Care and Use of Laboratory Animals. 1972, Institute for Laboratory Animal Resources, National Research Council--National Academy of Science.

Treatment protocol. Littermates aged 22 to 28 weeks were divided at random into control or treatment groups. It was assumed that these mature animals had active autoimmune disease. Earlier studies in this laboratory showed that PN mice uniformly developed glomerular deposits of immunoglobulin and complement after one month of age, and antiDNA antibodies were found in sera from $72 \%$ of PN mice at the age of 5-6 months (1). Twenty Group I mice ( 10 females, 10 males) and 20 Group II mice (10 females, 10 males) received daily subcutaneous injections of $0.1 \mathrm{ml} 0.15 \mathrm{M} \mathrm{NaCl}$. Twenty Group I mice ( 10 females, 10 males) and 18 Group II mice ( 7 females, 11 males) were subcutaneously injected with cyclophosphamide, $8 \mathrm{mg} / \mathrm{kg} / \mathrm{day}$, which was dissolved in 0.1 ml $0.15 M \mathrm{NaCl}$ immediately before use. This dose of cyclophosphamide was chosen because it suppressed autoimmune disease in NZB/NZW mice (7). Twenty Group I mice (10 females, 10 males) and 21 Group II mice ( 10 females, 11 males) received subcutaneous injections of hydrocortisone sodium succinate (Upjohn Company, Kalamazoo, Michigan), $10 \mathrm{mg} /$ $\mathrm{kg} /$ day. In an earlier study in this laboratory, this treatment regimen prevented glomerulonephritis and prolonged lifespans in young female NZB/NZW mice (8).

Mice were bled from the orbital plexus before treatment and after 24 and 52 weeks of treatment. Terminal blood samples were obtained from 48 mice. Sera for ANA tests and anti-DNA determinations were stored in sealed capillary tubes at $-20^{\circ} \mathrm{C}$. At each bleeding, leukocytes were counted in the conventional manner and blood films were prepared and stained with Wright's stain. Differential counts of 100 white blood cells (WBC) on each slide were performed.

Therapy continued until death. Mice were examined daily, and animals were killed when they appeared moribund or developed palpable masses. Complete postmortem examinations were performed according to a protocol described in another publication (9).

Histologic studies. Tissue sections stained with hematoxylin and eosin were examined for infection, neoplasia, and vasculitis. Severity of renal disease was scored by counting the number of abnormalities in 20 glomeruli in a $4 \mu$ cross section of each kidney. This method has been used to assess severity of glomerulonephritis in groups of NZB/NZW mice which received either saline (controls) or therapy with immunosuppressive drugs (8).

Autoantibodies. Undiluted serum was tested for heter- ogeneous ANA on guinea pig liver substrate, by use of an indirect immunofluorescent method (1). A modification of the Farr technique was used to measure specific anti-DNA antibodies. This assay quantitated the percentage of ${ }^{14} \mathrm{C}$-labeled KB cell-derived DNA bound by $0.015 \mathrm{ml}$ of heat-inactivated mouse serum (7). In this laboratory, values greater than $20 \%$ are positive for anti-DNA.

Statistical analysis. Student's $t$ test and chi-square tests were performed as described by Snedecor and Cochran (10).

\section{RESULTS}

Longevity. Mean ages at death in control and treated mice are listed in Table 1. Based upon observations of 203 PN mice in this laboratory (1), it was expected that untreated female PN mice would die prematurely with renal disease and vasculitis. In the current therapeutic study, mean longevity was 53 weeks $( \pm 4 \mathrm{SE})$ in female control mice and 65 weeks $( \pm 5)$ in male control mice. The difference in mean longevity in untreated mice of both sexes was not significant $(P>$ 0.05 ). Mean lifespans were similar in treated and control mice of both sexes, and therapy with cyclophosphamide or hydrocortisone did not increase longevity in PN mice.

Twenty-one mice died of infections when they were 28 to 83 weeks of age. Most of these animals had glomerulonephritis and/or arteritis. Premature deaths of infected mice did not influence mean longevity in groups of control or treated mice. When infected mice were deleted from longevity figures, mean lifespans were: control mice-females 51, males 67; cyclophosphamide-treated mice - females 56, males 61; hydrocortisone-treated mice-fermales 63, males 57 weeks.

Causes of death. Postmortem examinations showed that renal disease and vasculitis caused death in 23 of 40 control mice (Table 2). Treatment did not reverse autoimmune disease in PN mice. Death was attributed to glomerulonephritis and arteritis in 15 of 38

Table 1. Mean ages at death in control and treated PN mice

\begin{tabular}{lcc} 
& Females & Males \\
\cline { 2 - 3 } Control $^{*}$ & $53 \pm 4 \dagger$ & $65 \pm 5$ \\
Cyclophosphamide $\neq$ & $(20)$ & $(17)$ \\
Hydrocortisone & $58 \pm 3$ & $59 \pm 4$ \\
& $65 \pm 4$ & $57 \pm 5$ \\
& $(17)$ & $(17)$
\end{tabular}

* $0.1 \overline{\mathrm{ml} 0.15 \mathrm{M}} \overline{\mathrm{NaCl} / \mathrm{d}}$ ay by subcutaneous injection.

$\dagger$ Mean weeks of age at death \pm SE. Parentheses enclose numbers of mice in each group which were examined postmortem. Mice dying of iatrogenic causes or lost by autolysis were excluded from this table. $\$ 8 \mathrm{mg} / \mathrm{kg} /$ day by subcutaneous injection. $\$ 10 \mathrm{mg} / \mathrm{kg} /$ day by subcutaneous injection. 
Table 2. Causes of death in control and treated PN mice

\begin{tabular}{|c|c|c|c|c|c|c|c|c|}
\hline & $\begin{array}{c}\text { Renal } \\
\text { disease, } \\
\text { vasculitis }\end{array}$ & Infection* & Neoplasm & Hydronephrosis & $\begin{array}{c}\text { Pulmonary } \\
\text { edema }\end{array}$ & Hemorrhage & Other $†$ & Total \\
\hline \multicolumn{9}{|l|}{ Controls } \\
\hline Females & 16 & 2 & 1 & 0 & 0 & 0 & 1 & 20 \\
\hline Males & 7 & 6 & 2 & 1 & 0 & 0 & 4 & 20 \\
\hline \multicolumn{9}{|c|}{ Cyclophosphamide } \\
\hline Females & 10 & 5 & 1 & 0 & 0 & 1 & 1 & 18 \\
\hline Males & 5 & 6 & 0 & 0 & 5 & 1 & 3 & 20 \\
\hline \multicolumn{9}{|c|}{ Hydrocortisone } \\
\hline Females & 12 & 2 & 3 & 0 & 0 & 0 & 4 & 21 \\
\hline Males & 11 & 0 & 1 & 3 & 0 & 0 & 5 & 20 \\
\hline
\end{tabular}

* Death from infection occurred only in Group I mice, which were maintained in conventional animal quarters. Group II mice in a laminar flow hood did not die with infections.

† This category includes mice which died of iatrogenic causes during routine orbital bleeding (4) and mice lost by autolysis ( 8 ). In 6 instances ( 2 control mice, 3 cyclophosphamide-treated mice, 1 hydrocortisone-treated mouse) there was minimal evidence of autoimmune disease and the cause of death could not be determined.

mice receiving cyclophosphamide and 23 of 41 mice receiving hydrocortisone. Group I mice, which were housed in the conventional manner, had a high incidence of infections. Twenty-one of 62 Group I mice died with purulent pneumonia, bronchiectasis, pyelonephritis, or abscesses. In contrast to group I mice, no infections were found in "clean" Group II mice in a laminar flow hood. An important finding was the small number of neoplasms in PN mice treated with cyclophosphamide or hydrocortisone. Based upon earlier experience with NZB/NZW mice, it was assumed that prolonged immunosuppressive therapy was oncogenic in mice with autoimmune disease $(8,9)$. In the current study, neoplasms were distributed equally among control mice ( 2 lymphomas, one sarcoma), cyclophosphamide-treated mice (one lymphoma), and hydrocortisone-treated mice ( 3 sarcomas, one squamous cell carcinoma). Three neoplasms arose in Group I mice, and 5 neoplasms were found in Group II mice.

Autoantibodies. Positive tests for heterogeneous ANA are listed in Table 3. In control mice, numbers of positive tests increased with age. Twenty-four weeks af-

Table 3. Autoantibodies in control and treated PN mice

\begin{tabular}{|c|c|c|c|c|}
\hline \multirow[b]{2}{*}{ Antibodies } & \multicolumn{4}{|c|}{ Weeks of treatment } \\
\hline & 0 & 24 & 52 & Terminal \\
\hline \multicolumn{5}{|l|}{$A N A^{*}$} \\
\hline \multicolumn{5}{|l|}{ Controls } \\
\hline Females & 67 & 100 & 100 & 88 \\
\hline Males & 50 & 69 & 100 & 82 \\
\hline \multicolumn{5}{|c|}{ Cyclophosphamide } \\
\hline Females & 61 & 83 & 100 & 47 \\
\hline Males & 44 & 64 & 67 & 38 \\
\hline \multicolumn{5}{|l|}{ Hydrocortisone } \\
\hline Females & 58 & 86 & 88 & 71 \\
\hline Males & 53 & 40 & 33 & 47 \\
\hline \multicolumn{5}{|l|}{ Anti-DNA $\dagger$} \\
\hline \multicolumn{5}{|l|}{ Controls } \\
\hline Females & $27 \pm 2$ & $26 \pm 3$ & $36 \pm 2$ & $29 \pm 3$ \\
\hline Males & $23 \pm 1$ & $27 \pm 2$ & $27 \pm 2$ & $27 \pm 2$ \\
\hline \multicolumn{5}{|c|}{ Cyclophosphamide } \\
\hline Females & $23 \pm 1$ & $27 \pm 2$ & $35 \pm 2$ & $29 \pm 2$ \\
\hline Males & $23 \pm 1$ & $22 \pm 1$ & $32 \pm 3$ & $25 \pm 2$ \\
\hline \multicolumn{5}{|l|}{ Hydrocortisone } \\
\hline Females & $22 \pm 1$ & $34 \pm 3$ & $27 \pm 3$ & $25 \pm 2$ \\
\hline Males & $22 \pm 1$ & $23 \pm 2$ & $32 \pm 2$ & $27 \pm 2$ \\
\hline
\end{tabular}

* Percent of mice with positive indirect immunofluorescent tests for ANA.

$\dagger$ Mean \pm SE. A modification of the Farr technique was used to test sera for specific antibodies to DNA. Values are expressed as percent of ${ }^{14} \mathrm{C}$-labeled DNA bound to $0.015 \mathrm{ml}$ of mouse serum. 
ter the study began, positive ANA tests were found in $100 \%$ of control female mice and $69 \%$ of control male mice. In the cyclophosphamide treatment group, agedependent increases in numbers of positive tests were similar to untreated control mice. When hydrocortisone-treated mice were bled 24 to 52 weeks after the study began, numbers of positive ANA tests in male mice were decreased compared to control mice. This trend suggested that hydrocortisone therapy suppressed ANA response in male PN mice. However, chi-square analysis showed that numbers of positive tests were not decreased significantly in treated animals compared to controls.

During the 52-week period of observation, mean anti-DNA antibody levels increased from 27 to $36 \%$ in female control mice. Mean anti-DNA values did not increase with age in untreated male mice. While PN mice of both sexes received prolonged treatment with cyclo- phosphamide or hydrocortisone, anti-DNA levels remained similar to controls (Table 3).

WBC counts. Serial WBC counts in control and treated mice at 0,24 , and 52 weeks are illustrated in Figure 1. At the start of the study, mean peripheral WBC counts were $5036( \pm 344)$ in female control mice and $7812( \pm 597)$ in male control mice. Modest age-related decreases of circulating leukocytes were noted in control mice of both sexes. After 24 weeks of treatment, mice receiving cyclophosphamide had significant suppression of WBC counts compared to corresponding control mice (for females $P<0.005$; for males $P<$ 0.005 ). Suppressed peripheral WBC persisted after 52 weeks of cyclophosphamide therapy. At this point in the study, differences in mean leukocyte counts in cyclophosphamide-treated male PN mice compared to controls were significant at the 0.05 level. Treatment with hydrocortisone for 24 weeks was associated with signifi-

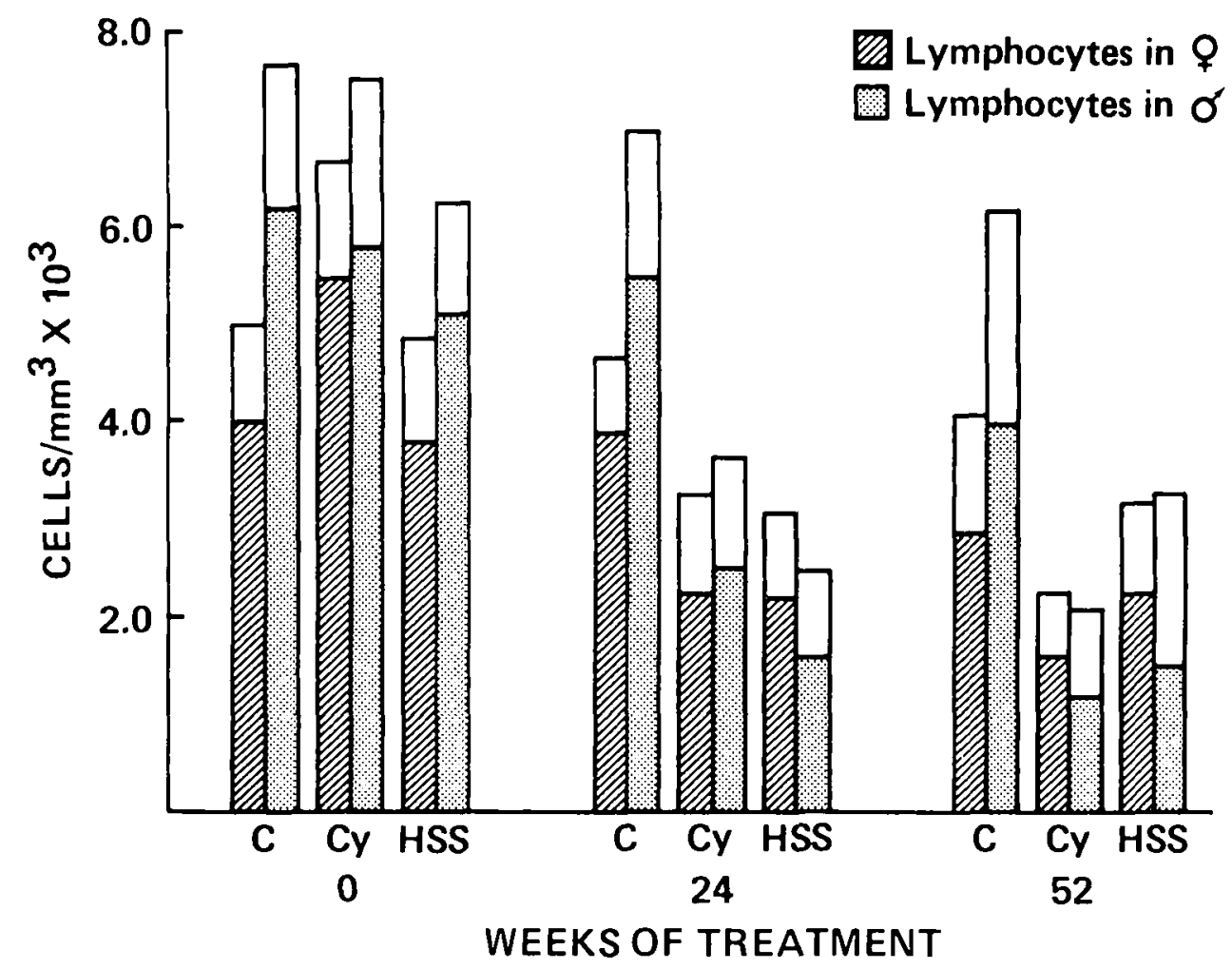

Figure 1. This graph illustrates mean white blood cell (WBC) counts and absolute lymphocyte counts (cells/ $\mathrm{mm}^{3}$ ) in PN mice at the start of treatment and after 24 and 52 weeks of treatment with cyclophosphamide (Cy) or hydrocortisone sodium succinate (HSS). Control mice (C) received saline. Each bar represents the mean total WBC count for a group of mice; shaded areas indicate mean absolute lymphocyte counts. Twentyfour weeks after the study began, WBC counts and lymphocyte counts in both groups of treated mice were depressed significantly compared to corresponding control mice. After 52 weeks, significant suppression of WBC counts and lymphocyte counts persisted in male mice that were treated with cyclophosphamide or hydrocortisone. 
cant decreases in total WBC counts in both female mice $(P<0.001)$ and male mice $(P<0.001)$ compared to female and male control mice. In the 15 hydrocortisonetreated mice which survived until week 52 of the study, leukocytes were suppressed. In male mice in this treatment group, the mean WBC count at 52 weeks was decreased significantly compared to control mice $(P<$ 0.05).

Mean absolute lymphocyte counts are represented by shaded areas within the bars in Figure 1. In control mice, lymphocyte counts fell during the first year of the study. In mice receiving cyclophosphamide or hydrocortisone, selective losses of lymphocytes accounted for most of the leukopenia observed after 24 and 52 weeks of treatment.

Renal histology. Table 4 lists mean glomerular lesion scores and vascular abnormalities in kidneys from 107 control and treated mice. In untreated mice, mesangial thickening and hypercellularity, basement membrane thickening, glomerular hypercellularity, and fibrinoid degeneration were reflected in mean glomerular lesion scores of $33( \pm 3)$ in females and $25( \pm 3)$ in males. Periarterial infiltrates were common, and fibrinoid necrosis of renal arteries occurred in $19 \%$ of control mice. In female mice treated with cyclophosphamide, the mean glomerular lesion score of $20( \pm 2)$ was suppressed significantly compared to control female mice $(P<0.01)$. Periarterial lymphocytes were rare, and the incidence of renal arteritis was $5 \%$. In contrast to the cyclophosphamide treatment group, mice that received hydrocortisone had renal lesions similar to untreated control mice.

\section{DISCUSSION}

This report describes resistance to immunosuppressive therapy in a strain of inbred mice which spontaneously develop autoantibodies and glomerulonephritis. The serologic and histologic abnormalities in PN mice closely resemble SLE in humans, and they represent a new murine model of lupus (1). A recent report described ANA in sera from PN mice at 5 months of age, and $80 \%$ of PN mice were ANA-positive at the age of 10 months. Anti-DNA were found in sera from $76 \%$ of PN mice when they were 10 months old. Deposits of immunoglobulins and complement appeared in renal glomeruli at 2 to 4 weeks of age, and examination of renal tissue by electron microscopy showed thick glomerular basement membranes and dense intramembranous deposits. Mean ages at death were 11.6 months in female mice and 15.8 months in male mice.
Table 4. Renal lesions in control and treated PN mice

\begin{tabular}{lccc}
\hline & $\begin{array}{c}\text { Glomerular } \\
\text { lesions* }\end{array}$ & $\begin{array}{c}\text { Periarterial } \\
\text { lymphocytes } \dagger\end{array}$ & Arteritisł \\
\hline Controls & $33 \pm 3$ & $3(0-4)$ & $3 / 20$ \\
$\quad$ Females & $25 \pm 3$ & $2(0-4)$ & $4 / 17$ \\
$\quad$ Males & $20 \pm 2 \S$ & $0(0-2)$ & $1 / 18$ \\
Cyclophosphamide & $19 \pm 2$ & $0(0-1)$ & $1 / 19$ \\
$\quad$ Females & & & \\
$\quad$ Males & $32 \pm 3$ & $2(0-4)$ & $1 / 18$ \\
Hydrocortisone & $27 \pm 3$ & $0(0-3)$ & $0 / 15$ \\
$\quad$ Females & Males & & \\
\hline
\end{tabular}

* Mean number of abnormalities counted in 20 glomeruli \pm SE.

$\dagger$ Median (range). Periarterial lymphocytes were scored on a scale of 0 to $4+$.

$\ddagger$ Number of kidneys with arteritis/number of kidneys examined. $\S$ Compared to female control mice, $P<0.01$.

The most common causes of death were glomerulonephritis and arteritis (1).

Earlier therapeutic studies showed that established autoimmune disease in NZB/NZW mice responded to treatment with cyclophosphamide or hydrocortisone. When 5-month-old female NZB/NZW mice received cyclophosphamide $4.5 \mathrm{mg} / \mathrm{kg} / \mathrm{day}$ for 3 months, autoantibody levels were suppressed and lifespans were prolonged (2). Treatment with the corticosteroid drug, betamethasone, suppressed antinuclear antibodies and glomerulonephritis in adult female New Zealand mice; therapy was begun when the mice were 5 to 6.5 months of age (3). In the current study, treatment was started after autoimmune disease was established in PN mice. These animals received doses of cyclophosphamide and hydrocortisone which were effective in preventing glomerulonephritis and prolonging lifespans in NZB/NZW mice $(7,8)$. However, careful monitoring of longevity, autoantibodies, and renal histology in control and treated mice showed that treatment failed to alter the course of disease in PN mice.

The poor response to therapy in PN mice compared to New Zealand mice may reflect different rates of drug metabolism and turnover in two genetically different strains of mice. However, the striking suppression of total WBC and lymphocyte counts in PN mice treated with cyclophosphamide or hydrocortisone provided evidence that levels of both drugs were capable of controlling bone marrow activity. It is also possible that established autoimmune disease in PN mice is unusually resistant to treatment. Additional experiments would be required to determine if therapeutic inter- 
vention at an early age can prevent renal disease and prolong life in PN mice.

Earlier studies in this laboratory provided evidence that cyclophosphamide was oncogenic in NZB/ NZW mice. When 20 hybrid New Zealand mice aged 4 to 24 weeks received life-long treatment with cyclophosphamide, $8 \mathrm{mg} / \mathrm{kg} /$ day, neoplasms appeared in 17 mice. Seven animals, aged 17 to 22 weeks when the study began, were considered to have established autoimmune disease at the start of therapy (11). All 7 of these mature mice developed neoplasms after 58 to 108 weeks of treatment. The pattern of oncogenesis was the same in mice which were either young or mature at the beginning of the study (9). The oncogenic properties of cyclophosphamide in NZB/NZW mice with active disease have been recorded by other investigators. Russell and Hicks (4) treated 192 female NZB/NZW mice aged 120-200 days with cyclophosphamide, $1.8 \mathrm{mg} /$ mouse/ week. Twenty-nine percent of the treated mice developed neoplasms. In another therapeutic study, tumor incidence of 22 percent was observed when female NZB/NZW mice aged 6 to 12 months received daily or intermittent doses of cyclophosphamide (5).

The current therapeutic study itilizing PN mice showed that oncogenesis is not an inevitable complication of prolonged therapy of autoimmur, disease. Successful suppression of disease appears to orrelate with increased numbers of neoplasms. In NZB, NZW mice with active disease, cyclophosphamide therapy increased longevity and accelerated appearance of neoplasms $(4,5)$. In the current study, the failure to control autoimmune disease in PN mice was associated with a low incidence of neoplasms in treated animals.

Another factor that may be associated with druginduced tumors in mice is the presence of potentially oncogenic type $C$ viruses. These viruses are demonstrated by electron microscopy in lymphatic tissues of New Zealand mice (12), and they are cultured from NZB/NZW mouse cells (13). Expression of xenotropic type $\mathrm{C}$ viruses in NZB mice is a genetically controlled trait (14). In this laboratory, we have not been able to identify type $C$ viral particles by electron microscopy in thymic tissue from 7 adult PN mice (unpublished data). Results of this preliminary study did not exclude the possibility that PN mice carry type $C$ viruses. Nevertheless, it may be postulated that PN mice lack the genetically determined ability to produce large numbers of type $\mathrm{C}$ viruses. In the chronically immunosuppressed state, the inability to generate oncogenic viruses may protect an animal from the appearance of neoplasms.

\section{ACKNOWLEDGMENTS}

The valuable technical assistance of Margaret Ketterer, Barbara Boddy, and Cheryl Hassett is acknowledged with gratitude.

\section{REFERENCES}

1. Walker SE, Gray RH, Fulton M, Wigley RD, Schnitzer B: Palmerston North mice, a new animal model of systemic lupus erythematosus. J Lab Clin Med 92:932-945, 1978

2. Gelfand MC, Steinberg AD: Therapeutic studies in NZB/ W mice. II. Relative efficacy of azathioprine, cyclophosphamide and methylprednisolone. Arthritis Rheum 15:247-252, 1972

3. Casey TP: Systemic lupus erythematosus in NZB $\times$ NZW hybrid mice treated with the corticosteroid drug betamethasone. J Lab Clin Med 71:390-399, 1968

4. Russell PJ, Hicks JD: Cyclophosphamide treatment of renal disease in $(\mathrm{NZB} \times \mathrm{NZW})$ Fl hybrid mice. Lancet $1: 440-446,1968$

5. Hahn BH, Knotts $\mathrm{L}, \mathrm{Ng} \mathrm{M}$, Hamilton TR: Influence of cyclophosphamide and other immunosuppressive drugs on immune disorders and neoplasia in NZB/NZW mice. Arthritis Rheum 18:145-152, 1975

6. Wigley RD, Couchman KG, Maule R: Polyarteritis nodosa: the natural history of a spontaneously occurring model in outbred mice. Aust Ann Med 4:319-327, 1970

7. Walker SE, Bole GG Jr: Selective suppression of autoantibody responses in NZB/NZW mice treated with longterm cyclophosphamide. Arthritis Rheum 18:265-272, 1975

8. Walker SE, Anver MR, Schechter SL, Bole GG Jr.: Prolonged lifespan and high incidence of neoplasms in NZB/ NZW mice treated with hydrocortisone sodium succinate. Kidney Int 14:151-157, 1978

9. Walker SE, Bole GG Jr.: Augmented incidence of neoplasia in NZB/NZW mice treated with long-term cyclophosphamide. J Lab Clin Med 82:619-633, 1973

10. Snedecor GW, Cochran WG: Statistical Methods. Sixth edition. Ames, lowa, Iowa State University Press, 1967, 100-109, 215-220

11. Howie JB, Helyer BJ: The immunology and pathology of NZB mice. Adv Immunol 9:215-266, 1968

12. Prosser PR: Particles resembling murina leukaemia virus in New Zealand Black mice. Clin Exp Immunol 3:213226, 1968

13. Levy JA: Autoimmunity and neoplasia: the possible role of C type viruses. Am J Clin Path 62:258-280, 1974

14. Datta SK, Schwartz RS: Genetics of expression of xenotropic virus and autoimmunity in NZB mice. Nature $263: 412-415,1976$ 